\title{
A SAUDADE PORTUGUESA NA TOPONIMIA BRASILEIRA
}

\section{Antenor Nascentes}

Rio

Os navegadores portugueses que a partir do século XVI começaram a explorar os "mares nunca dantes navegados" à procura de novas terras para "dilatar a fé e o império", levavam consigo a saudade da terra natal e para mitigá-la muitas vezes davam às povoações fundadas nomes dos lugares onde nasceram.

Outro tanto faziam os espanhóis, os franceses, os ingleses, os holandeses.

Existiu uma Nova-Espanha, o México atual, uma Nova-lnglaterra, a New-England, uma Nova-França, o Canadá, uma Nova-Holanda, a Austrália.

O Brasil, por circunstâncias históricas, não pôde ser um Novo-Portugal.

Considerado uma simples ilha na ocasião do seu descobrimento, recebeu de Pedro Álvares Cabral o nome de Vera-Cruz, alterado mais tarde para Santa Cruz e finalmente para Brasil.

Entretanto não deixou de haver nas bandas da América uma Nova-Lusitânia, se bem que efêmera.

É o que nos informa Gabriel Soares de Sousa em seu Tratado descritivo do Brasil em 1587, pg. 4.

Este nome ainda aparece na Prosopopéia de Bento Teixeira, mas aplicado à capitania de Duarte Coelho Pereira (Pernambuco).

Mas se o nome da metrópole não foi aplicado ao extenso território descoberto, em compensação grande número de povoações receberam nomes e topônimos portugueses.

Há muitos topónimos brasileiros iguais a topónimos portugueses. 
Mas isto se explica naturalmente pela identidade de língua, na maioria dos casos. Nem todos estes topónimos idênticos se acham relacionados.

Xavier Fernandes, no segundo tomo de seus Topónimos e gentílicos, pgs. 9-14, enfileirou uma série de 129 topónimos luso-brasileiros, mas muitos deles representam apenas mera coincidência.

Assim, por exemplo, ela dá Aguas-Santas em Minas Gerais.

Este Águas-Santas de Minas Gerais nada tem que ver com Aguas Santas de Portugal. O nome foi dado em razão de águas medicinais existentes na localidade.

E como este, Barreiros, Brejo, Cardosos, Entre-Rios e tantos outros.

Por conseguinte, um estudo sôbre o assunto deve limitar-se aos que de fato representam transplantação de topónimo português.

Essa transplantação quase sempre se operou espontâneamente, graças ao concurso dos povoadores anónimos, saudosos da pátria distante.

Algumas vezes se deu por influência oficial, com o intuito de fazer desaparecer o topónimo aborígene, como aconteceu no Pará em 1758.

O capitão-general Francisco Xavier de Mendonça Furtado ordenou que se substituissem por topónimos portugueses os de origem tupi, visando assim a dissimular a origem indígena dos povoados em que se transfiguraram os aldeamentos organizados pelos jesuitas, incursos então na má vontade do marquês de Pombal.

A providência se destinava a impedir que o idioma dos índios continuasse a suplantar o dos colonizadores, pois, como nota Teodoro Sampaio, até o começo do século XVIII, a proporção entre as duas línguas faladas na colônia era mais ou menos de três para um, do tupi para o português.

Veremos, Estado por Estado, quais os topónimos idênticos 
que são transplantações de topónimos portugueses.

No Amazonas encontram-se: Borba, Silves, Barcelos, Badajoz, S. Paulo de Olivença (Olivença, entāo portuguesa).

São numerosos os do Pará: Alcobaça, Alenquer, Alter do Chão (antigo Borani), Almeirim (antigo Paru), Aveiro, Arraiolos, Bragança, Chaves, Colares, Esposende (antiga Tuaré), Faro, Mazagāo, Melgaço (antiga Guaricuru), Monsaraz, Monte Alegre (antiga Gurupatuba), Óbidos (antiga Pauxis), Oeiras (antiga Araticu), Ourém, Portel (antiga Arucará), Porto de Moz, Santarém (antiga Tapajós), Sintra, hoje Maracană, Soure, Tentúgal, Viseu.

Mazagão, antiga Vila Nova de Mazagão, foi criada em 1770 para nela serem localizados os soldados portugueses, veteranos das guerras de África, que tinham resistido aos mouros na cidade africana do mesmo nome.

O Maranhão, Estado onde é grande a influência portuguesa, até hoje, nem por isso conta muitos topónimos idênticos. Aparecem: Alcântara, Viana (talvez a do Castelo, que não a do Alentejo), Guimarães, Caxias.

Este último se repete no Sul, no Estado do Rio de Janeiro, onde foi mudado para Duque de Caxias por ocasião da revisão da nomenclatura geográfica e no Rio Grande do Sul, onde passou a chamar-se Caxias do Sul.

O Piauí apresenta: Amarante, Oeiras, Valença (talvez a do Minho), Jerumenha. Jerumenha, alteração de Jurumenha, recebeu de Martius uma incrivel etimologia tupi.

Oeiras antigamente se chamou Moxa. Quando foi escolhida em 1761 para capital da capitania do Piauí, recebeu do rei $D$. José I este nome em homenagem ao ministro Sebastião de CarvaTho e Melo, conde de Oeiras, mais tarde marquês de Pombal.

O Ceará conta: Sobral, Soure, Crato, Mecejana.

Não se pode pôr em dúvida o primeiro. Não há sobreiros no Brasil.

Apesar de reconhecer a existência de uma vila portuguêsa com o nome de Mecejana, apesar de reconhecer o étimo árabe des- 
te nome, José de Alencar dá a palavra como de origem tupi e significando "a abandonada". Tira do verbo cejar, que significa "abandonar" e diz que a desinência ana indica a pessoa que exercita a ação do verbo. Cejana significa "o que abandona". Junta a partícula mo do verbo mohang, "fazer", vem a palavra a significar "o que faz abandonar" ou "que foi lugar e ocasião de abandonar". Argumenta afirmando que, se o nome proviesse de Portugal, devia escrever-se Mecejana. Ora nos mais antigos documentos se encontra Mecejana com c, o que indicaria uma alteração pouco natural, quando o Ceará foi exclusivamente povoado por portugueses, os quais conservaram em sua pureza todos os outros nomes de origem lusitana (Iracema, ed. de 1936, pgs. 124 e 178). A argumentação de Alencar não convence, diante da certeza do étimo lusitano.

O Rio Grande do Norte apresenta Macau e Estremoz.

A Paraíba e Pernambuco não apresentam nenhum topónimo importante que nos interesse.

Alagoas, apenas Anadia.

Sergipe tem Badajoz.

A Baía conta: Abrantes, Barcelos, Belmonte, donde era senhor Pedro Álvares Cabral, o descobridor, que tocou em terras baianas em 1500, Alcobaça, Santarém, Trancoso, Olivença (hoje espanhola), Valença.

O Espírito Santo nada apresenta de importante.

O Estado do Rio de Janeiro apresenta Arcozelo, uma simples estação ferroviária. Lá existem Valença e Resende, que se prendem a personalidades portuguesas.

Valença tem a seguinte origem.

Em princípios do século XIX, o vigário de Sacra Damília do Tinguá, Manuel Comes Leal, mandou erigir, sob a invocação de N. S. da Glória, uma capela num antigo aldeamento de índios, fundado por José Rodrigues da Cruz e outros, entre a serra das Cruzes e a da Taquara. $O$ aldeamento, vila em 1819, cidade em 
1857, tomou então o nome de Valença em homenagem a D. Fernando José de Portugal, marquês de Aguiar, descendente dos nobres de Valença.

A cidade de Resende, segundo o testemunho de Aires do Casal, Corografia brasílica, II, 19, foi criada no governo de D. José Luís de Castro, segundo conde de Resende e quinto vice-rei do Brasil, sendo assim chamada em honra dele.

São Paulo apresenta a cidade de Montemor, Paranhos, Nova Louzã, e as estações ferroviárias Lusitânia e Miragaia. Houve uma antiga Queluz.

Paraná e Santa Catarina nada apresentam de importante.

O Rio Grande do Sul apresenta Alegrete, que não vem de topónimo.

Havia no local uma cidade cuja capela os espanhóis incendiaram em 1761.

O capitão-general marquês de Alegrete mandou reconstrui-la e então os habitantes, gratos, deram à localidade o nome do título do marquês.

Mato Grosso apresenta Melgaço.

Goiás nada conta que se possa atribuir a transplantação.

Finalmente, Minas Cerais possui Cedofeita, que lembra a igrejinha do Porto, construida às pressas pelo rei Teodemiro dos Suevos, para receber as relíquias de $\mathrm{S}$. Martinho, Ericeira que evoca a praia donde partiu para o exílio o rei D. Manuel II, Barbacena, nome de freguesia próxima de Elvas, Queluz (hoje Lafayette), lembrando o palácio real das cercanias de Lisboa, Matozinhos, que possui um santuário que é uma réplica do que existe no Porto, Mariana e S. Joáo del-Rei. Mariana era a vila do Carmo. Passou a ser cidade em 25 de Abril de 1745, recebendo este nome em honra de D. Maria Ana d'Austria, esposa do rei D. João V.S. João del-Rei era o antigo arraial do Rio das Mortes. Por auto de 8 de Dezembro de 1713, D. Brás Baltasar da Silveira, governador e capitão-general de S. Paulo e Minas, apelidou com o no- 


\section{$-107-$}

me de S. João del-Rei e mandou que com este título fosse de todos o nomeado o arraial, em memória de El-Rei Nosso Senhor. Perto de S. João del-Rei fica a antiga vila de S. José do Rio das Mortes, depois S. José del-Rei, hoje Tiradentes, cujo nome se atribui ao príncipe real $D$. José, mais tarde rei $D$. José I, filho de D. João $V$. Feita uma homenagem ao pai, julgaram de bom aviso fazer outra ao filho.

Não serão muitos estes nomes, mas são os suficientes para provar que o lusíada, coitado!, no dizer de António Nobre que levado por seu gênio aventureiro deixava os pátrios lares, deles jamais se esquecia. 